\title{
Pengaruh Tingkat Pendapatan, Penurunan Tarif, Dan Perubahan Cara Pembayaran Terhadap Kepatuhan Wajib Pajak UMKM Masa Pandemi Covid-19
}

\author{
Lutfah Fadilah $^{1}$, Asrofi Langgeng Noermansyah ${ }^{2}$, Krisdiyawati ${ }^{3}$, \\ 1,2.3) Politeknik Harapan Bersama \\ ${ }^{1}$ lutfa.fadil@gmail.com, ${ }^{2}$ asrofi_langgeng@poltektegal.ac.id, ${ }^{3}$ kris.diyawati@ gmail.com
}

*Penulis Korespondensi

$\begin{array}{ll}\text { Diajukan } & : \text { 30 Juni } 2021 \\ \text { Disetujui } & : \text { 26 Juli } 2021 \\ \text { Dipublikasikan } & : \text { 1 Agustus 2021 }\end{array}$

\begin{abstract}
This study aims to determine the effect of income levels, tariff reductions and changes in payment methods on MSME taxpayer compliance during the COVID-19 pandemic. Data collection techniques used questionnaires, observations, interviews, documentation and literature studies. The population in this study were all MSME taxpayers registered at KPP Pratama Tegal. The number of samples used as many as 50 respondents with the sampling method using purposive sampling method. The data analysis method used multiple linear regression analysis. The results of testing the first hypothesis show that the income level variable has an effect on MSME taxpayer compliance during the covid-19 pandemic. This shows that the higher the level of income received, the greater the compliance of MSME taxpayers. The results of testing the second hypothesis show that the rate reduction variable has no effect on MSME taxpayer compliance during the covid-19 pandemic. This shows that someone who does not comply with his obligations as a taxpayer, then even a low tax rate does not affect the level of compliance. The results of testing the third hypothesis show that the variable changes in payment methods affect MSME taxpayer compliance during the covid-19 pandemic. This means that changes in the method of paying taxes can improve MSME taxpayer compliance so that the easier the tax payment method used, the MSME taxpayer compliance will increase.
\end{abstract}

Keywords : Income Level, Decrease Rate, Changes In Payment Methods, Taxpayer Compliance

\section{PENDAHULUAN}

Pajak merupakan unsur penting di Negara Indonesia karena pajak merupakan sumber pendapatan Negara yang terbesar. Tanpa adanya pajak maka Negara Indonesia akan mengalami permasalahan dalam pembangunan dan dalam upaya mensejahterakan masyarakat. Menurut Prof. Dr. Rochmat Soemitro, S.H, pajak adalah iuran rakyat kepada kas Negara berdasarkan undang-undang (yang dapat dipaksakan) dengan tidak mendapat jasa timbal-balik (kontraprestasi) yang langsung dapat ditunjukkan, digunakan untuk membayar pengeluaran umum Negara (Sukrisno \& Estralita, 2012). Oleh karena itu, pemerintah terus berupaya meningkat penerimaan negara dari pajak melalui beberapa sektor ekonomi masyarakat, salah satunya sektor usaha mikro, kecil dan menengah (UMKM).

Pemerintah telah memulai upaya intensif menyadarkan pelaku UMKM untuk membayar pajak karena sebelumnya fokus penagihan pajak hanya pada pelaku usaha besar. Kebijakan ini diharapkan akan menaikkan penerimaan pajak sekaligus memperluas basis penagihannya. Hal ini karena usaha mikro, kecil, dan menengah (UMKM) merupakan sektor ekonomi yang mempunyai peran cukup besar dalam perekonomian nasional. UMKM memiliki omset dan laba yang jauh lebih kecil dibandingkan dengan pelaku usaha besar tetapi keberadaan usaha ini banyak dijumpai di seluruh sudut wilayah Indonesia sehingga mampu memberikan sumbangsih yang berarti bagi pertumbuhan ekonomi. Akan tetapi, keberadaan jumlah UMKM yang banyak ternyata belum sebanding dengan kontribusi 
penerimaan pajak yang diberikan oleh pelaku UMKM. Hal tersebut menunjukkan bahwa tingkat kepatuhan pelaku UMKM dalam memenuhi kewajiban perpajakan masih sangat rendah (Direktorat Jenderal Pajak).

Kepatuhan pelaku UMKM yang sangat rendah adalah masalah pemerintah yang harus ditanggapi dengan serius. Sekarang ini, pelaku UMKM sedang dihadapkan dengan masa pandemi covid-19. Jika kepatuhan pelaku UMKM yang sebelumnya saja sudah sangat rendah maka adanya masa pandemi covid-19 ini akan mengakibatkan tingkat kepatuhan pelaku UMKM semakin lebih rendah lagi. Hal ini menunjukkan bahwa pemerintah harus berupaya agar kepatuhan pelaku UMKM tidak semakin lebih rendah. Upaya pemerintah tersebut yaitu dengan menerbitkan PMK No.44 tahun 2020. Dimana peraturan tersebut menjadi solusi terbaik pada masa pandemi covid-19 yang diharapkan mampu meningkatkan kepatuhan para pelaku UMKM dalam menjalankan kewajiban perpajakannya.

Kepatuhan pelaku UMKM dalam memenuhi kewajibannya dipengaruhi oleh beberapa faktor, salah satunya yaitu tingkat pendapatan. Pedapatan Pelaku UMKM merupakan objek pajak dalam pajak penghasilan saling terkait dengan besarnya pajak terutang yang akan dibayarkan. Pada masa pandemi covid-19 tingkat pendapatan pelaku UMKM akan mengalami penurunan dan akan menemukan kesulitan untuk membayar pajaknya. Hal ini menunjukkan bahwa tingkat pendapatan seseorang dapat mempengaruhi tingkat kepatuhan pelaku UMKM dalam memenuhi kewajibannya.

Faktor lain yang dapat mempengaruhi kepatuhan pelaku UMKM adalah penurunan tarif pajak. Terkait tarif pajak, pemerintah memberlakukan Peraturan Pemerintah No. 46 Tahun 2013 tentang Pajak Penghasilan atas Penghasilan dari usaha yang diterima atau diperoleh Wajib Pajak yang memiliki peredaran bruto tertentu yakni penghasilan yang belum dikurangkan dengan biaya-biaya berjumlah tidak melebihi Rp 4,8 miliar dalam 1 tahun dikenai tarif $1 \%$ (satu persen). Pemerintah pula merevisi dan mengganti peraturan tersebut dengan peraturan pemerintah nomor 23 tahun 2018 yaitu tentang penurunan tarif PPh final yang semula $1 \%$ dan kini diturunkan menjadi $0,5 \%$. Dengan adanya kebijakan ini, diharapkan dapat meningkatkan kepatuhan pelaku UMKM dalam memenuhi kewajiban perpajakannya.

Selain beberapa faktor diatas, pemerintah juga memanfaatkan adanya perkembangan teknologi yaitu dengan cara melakukan pembaruan mengenai pembayaran pajak yang bisa di lakukan secara online. Cara pembayaran yang awalnya secara manual harus ke kantor pajak sekarang bisa dilakukan dimana saja dengan menggunakan e-billing. Perubahan cara pembayaran ini diharapkan lebih memudahkan para pelaku UMKM yang sibuk dengan kegiatan usahanya agar memenuhi kewajiban perpajakan. Dengan adanya kemudahan tersebut, di harapkan tingkat kepatuhan pelaku UMKM dalam membayar pajak akan meningkat.

Kepatuhan wajib pajak di KPP Pratama Tegal dalam memenuhi kewajibannya masih rendah. Hal ini dibuktikan dengan hasil observasi dan wawancara kepada wajib pajak UMKM diketahui bahwa sebelum masa pandemi covid-19, masih banyak Wajib Pajak UMKM yang tidak mengetahui perubahan tarif PPh UMKM yang turun menjadi $0,5 \%$ dari sebelumnya $1 \%$. Hal itu disampaikan langsung oleh Wajib Pajak UMKM pada saat melakukan pelaporan SPT Tahunan. Selain itu, Pada masa pandemi covid-19 pemerintah membuat kebijakan agar wajib pajak melakukan pelaporan SPT Tahunan dan pembayaran pajak melalui online. Pada kenyataannya banyak wajib pajak yang kesulitan atas kebijakan pemerintah tersebut. Pada masa pandemi covid-19 juga banyak Wajib Pajak UMKM yang mengeluhkan terkait pendapatannya yang menurun dan kesulitan dalam membayar pajak. Hal-hal tersebut akan sangat berpengaruh pada tingkat kepatuhan wajib pajak UMKM dalam memenuhi kewajiban perpajakannya.

Hasil penelitian terdahulu yang dilakukan Ernawati (2014) menyatakan bahwa variabel tingkat pendapatan berpengaruh secara positif terhadap kepatuhan wajib pajak KPP pratama Bulukumba, sedangkan penelitian Isawati (2016) menunjukan bahwa variabel pendapatan berpengaruh negatif dan tidak berpengaruh signifikan terhadap kepatuhan wajib pajak dalam membayar pajak bumi dan bangunan. Hasil penelitian dari Nadhor (2019) menyatakan bahwa penurunan tarif pajak berpengaruh positif dan signifikan terhadap kepatuhan wajib pajak UMKM yang terdaftar di KPP Semarang Barat, sedangkan penelitian yang dilakukan oleh Yusro dan Kiswanto (2014) bahwa tarif pajak tidak berpengaruh terhadap kepatuhan wajib pajak Di Kabupaten Jepara. Hasil penelitian dari Wahyuningsih 
(2016) diketahui bahwa mekanisme pembayaran pajak berpengaruh positif signifikan terhadap kepatuhan wajib pajak UMKM bidang mebel di Surakarta.

Berdasarkan permasalahan dan hasil penelitian terdahulu maka penelitian ini akan mengkaji kembali pengaruh tingkat pendapatan, penurunan tarif dan perubahan cara pembayaran terhadap kepatuhan wajib pajak UMKM, dimana penelitian ini sejenis dengan penelitian Nadhor (2019) dan penelitian Wahyuningsih (2016). Akan tetapi penelitian ini mengembangkan dari penelitian sebelumnya dengan beberapa perbedaan yaitu menambahkan variable independen berupa tingkat pendapatan dan objek yang diteliti pada wajib pajak UMKM di wilayah KPP Pratama Tegal yang terkena dampak pandemi covid-19.

\section{Kepatuhan Wajib Pajak}

\section{STUDI LITERATUR}

Menurut Keputusan Menteri Keuangan No. 544/KMK.04/2000 menyatakan bahwa kepatuhan perpajakan adalah tindakan wajib pajak dalam pemenuhan kewajiban perpajakan sesuai dengan ketentuan peraturan perundang-undangan dan peraturan pelaksanaan perpajakan yang berlaku di suatu negara (Syah \& Krisdiyawati, 2017). Kepatuhan wajib pajak dibagi menjadi dua, yaitu kepatuhan pajak formal dan kepatuhan pajak material. Kepatuhan pajak formal adalah kepatuhan yang diatur sesuai dengan ketentuan dalam undang-undang perpajakan. Kepatuhan pajak material adalah suatu keadaan saat wajib pajak secara substantif memenuhi semua ketentuan material perpajakan, yakni sesuai isi dan jiwa undang-undang perpajakan (Ramdan, 2017)

\section{Tingkat Pendapatan}

Pendapatan adalah tanggung jumlah uang atau nilai yang selama tahun takwim diperoleh seseorang dari usaha dan tenaga, barang tak bergerak, harta bergerak, hak atas pembayaran berkala, dan tambahan harta yang ternyata dalam tahun takwim kecuali jika hal sebaliknya dibuktikan oleh wajib pajak (Haswidar, 2016).

\section{Penurunan Tarif}

Tarif merupakan suatu pedoman dasar dalam menetapkan berapa besarnya utang pajak orang pribadi maupun badan, selain sebagai sarana keadilan dalam penetapan utang pajak. Berdasarkan PP No.46 Tahun 2013, UMKM di Indonesia yang memiliki omset kurang dari 4,8 Milyar dalam satu tahun dikenakan PPh final sebesar 1\%. Pada bulan Juli 2018 pemerintah kembali menerbitkan PP No.23 Tahun 2013 tentang pajak penghasilan atas penghasilan dari usaha yang diterima atau diperoleh wajib pajak yang memiliki peredaran bruto tertentu. Dalam peraturan ini pemerintah menurunkan tarif $\mathrm{PPh}$ final dari $1 \%$ menjadi 0,5\% (Marasabessy, 2020).

\section{Sistem Pembayaran Pajak}

Perubahan cara pembayaran dari sistem manual ke online adalah penerapan e-billing yang sesuai dengan Peraturan Menteri Keuangan (PMK) Nomor 32/PMK.05/2014, dimana mulai tanggal 1 juli 2016 wajib pajak dapat menggunakan mekanisme e-billing direktorat jenderal pajak untuk membayar pajak yang terutang. E-Billing adalah metode pembayaran pajak secara elektronik menggunakan kode billing. Kode billing sendiri adalah kode identifikasi yang diterbitkan melalui sistem billing atas suatu jenis pembayaran atau setoran pajak yang akan dilakukan Wajib Pajak. Sementara billing system adalah sistem yang menerbitkan kode billing untuk pembayaran atau penyetoran penerimaan negara secara elektronik, tanpa perlu membuat Surat Setoran (SSP, SSBP, SSPB) manual (E. Handayani, 2018).

\section{Hipotesis Penelitian}

\section{Pengaruh Tingkat Pendapatan terhadap kepatuhan Wajib Pajak UMKM}

Faktor ekonomi merupakan hal yang sangat fundamental dalam hal melaksanakan kewajiban. Masyarakat yang miskin akan menemukan kesulitan untuk membayar pajak. Kebanyakan mereka akan memenuhi kebutuhan hidup terlebih dahulu sebelum membayar pajak. Karenanya tingkat pendapatan 
seseorang dapat memengaruhi bagaimana seseorang tersebut memiliki kesadaran dan kepatuhan akan ketentuan hukum dan kewajibannya.

Selain itu dalam teori ekonomi dikatakan bahwa I atau Income $=\mathrm{C}$ atau Consumtion, dimana besarnya penghasilan akan sama dengan besarnya konsumsi. Konsumsi disini termasuk juga pengeluaran untuk membayar pajak karena wajib pajak dianggap melakukan tindakan konsumsi yaitu menghabiskan nilai guna dari suatu barang, dalam hal ini yang dimaksud adalah nilai guna atas tanah dan bangunan (Haswidar, 2016). Hasil penelitian sebelumnya yang dilakukan oleh Ernawati (2014) terkait identifikasi kemampuan dan kemauan membayar masyarakat berpenghasilan menengah rendah menunjukan bahwa variabel pendapatan memiliki pengaruh terhadap kesediaan membayar pajak. (Ernawati, 2014)

Berdasarkan uraian diatas maka dapat dirumuskan hipotesis penelitian ini sebagai berikut :

$\mathrm{H}_{1}$ : Tingkat pendapatan berpengaruh positif terhadap kepatuhan wajib pajak UMKM masa pandemi Covid-19 pada KPP Pratama Tegal.

\section{Pengaruh Penurunan Tarif terhadap kepatuhan Wajib Pajak UMKM}

Tarif pajak merupakan suatu pedoman dasar dalam menetapkan berapa besarnya utang pajak orang pribadi maupun badan, selain sebagai sarana keadilan dalam penetapan utang pajak. Pemerintah menurunkan pajak penghasilan (PPh) Final bagi pelaku usaha mikro kecil dan menengah (UMKM) yang semula $1 \%$ menjadi $0,5 \%$ mulai 1 Juli 2018 . Tarif pajak yang rendah akan meningkatkan utility wajib pajak sehingga memberikan inisiatif dalam melaporkan penghasilan kepada administrasi pajak,

Penurunan pajak UMKM ini nantinya akan mengurangi biaya bagi pelaku usaha UMKM, sehingga kemungkinan mereka akan mengembangkan usaha kecilnya menjadi usaha menengah, lalu usaha menengah mengembangkannya menjadi usaha besar. Dampak dari penurunan tarif pajak UMKM ini diharapkan akan meningkatkan kesadaran wajib pajak UMKM dalam membayar pajak. Sehingga dengan hal ini akan meningkatkan pendapatan penerimaan pajak untuk Negara. Mengingat kepatuhan pajak pelaku usaha mikro kecil dan menengah dinilai masih minim. Jadi dengan diturunkannya tarif pajak UMKM diharapkan akan meningkatkan kepatuhan wajib pajak UMKM.

Hasil penelitian sebelumnya yang dilakukan oleh Nadhor (2019) menyimpulkan bahwa penurunan tarif pajak berpengaruh positif terhadap persepsi wajib pajak mengenai kepatuhan wajib pajak UMKM (Nadhor, 2019). Menurut Ramdan (2017) menyimpulkan bahwa perubahan tarif pajak berpengaruh positif terhadap kepatuhan wajib pajak UMKM (Ramdan, 2017). Hal ini berarti bahwa adanya perubahan tarif pajak yang semakin menurun maka kepatuhan wajib pajak akan semakin baik.

Berdasarkan uraian diatas maka dapat dirumuskan hipotesis penelitian ini sebagai berikut :

$\mathrm{H}_{2}$ : Penurunan Tarif berpengaruh positif terhadap kepatuhan wajib pajak UMKM masa pandemi Covid19 pada KPP Pratama Tegal.

\section{Pengaruh Perubahan Cara Pembayaran terhadap kepatuhan Wajib Pajak UMKM}

Sejalan dengan pengenaan pajak bagi UMKM dengan diterbitkannya Peraturan Pemerintah Nomor 46 tahun 2013, Direktorat Jenderal Pajak juga memberlakukan pembayaran pajak secara elektronik yang diatur dengan Peraturan Direktur Jenderal Pajak nomor PER-05/PJ/2017 tanggal 4 April 2017. Pada dasarnya Peraturan ini menekankan perubahan cara pembayaran pajak yang tadinya menggunakan Surat Setoran Pajak (manual) menjadi Surat Setoran Elektronik (SSE) yang dikelola oleh Sistem Elektronik Direktorat Jenderal Pajak (DJP) yang terhubung dengan Modul Penerimaan Negara. Perubahan cara pembayaran pajak secara elektronik membuat wajib pajak lebih mudah dan lebih cepat dalam membayar pajak karena bisa kapan saja dan dimana saja menunaikan kewajiban tersebut. Hal ini dapat menjadikan wajib pajak lebih patuh dalam membayar pajak.

Hasil penelitian sebelumnya yang dilakukan oleh Kusnandar (2019) menyimpulkan bahwa perubahan cara pembayaran pajak berpengaruh positif terhadap kepatuhan wajib pajak UMKM. Hal ini berarti perubahan cara pembayaran pajak dapat meningkatkan kepatuhan wajib pajak UMKM sehingga semakin baik sistem Pembayaran pajak yang digunakan oleh Wajib Pajak UMKM maka kepatuhan wajib pajak UMKM akan semakin baik.

Berdasarkan uraian diatas maka dapat dirumuskan hipotesis penelitian ini sebagai berikut : 
$\mathrm{H}_{3}$ : Perubahan Cara Pembayaran berpengaruh positif terhadap kepatuhan Wajib Pajak UMKM masa pandemi Covid-19 pada KPP Pratama Tegal.

\section{METODE}

Jenis penelitian ini adalah penelitian kuantitatif, dimana penelitian ini terdapat satu variable dependen dan tiga variable independen. Jenis data yang digunakan yaitu data kualitatif dan data kuantitatif (Sangadji, 2010). Data kualitatif berupa data yang diperoleh dari jawaban kuesioner yang disebarkan kepada sejumlah responden. Data kuantitatif berupa hasil perhitungan kuesioner. Sumber data dalam penelitian ini yaitu data primer yang berupa persepsi responden atas kuisioner yang diberikan. Populasi dalam penelitian ini adalah wajib pajak pelaku UMKM yang terdaftar di KPP Pratama Tegal hingga tahun 2019 yang berjumlah sebanyak 15.211 orang. Teknik pengambilan sampel dalam penelitian ini menggunakan jenis Non probability sampling yaitu dengan metode purposive sampling (Sugiyono, 2016). Adapun kriteria sampel adalah UMKM perseorangan yang memiliki omset kurang dari Rp 4,8 Miliar per tahun, wajib pajak UMKM yang masih aktif dan berlokasi di kabupaten Brebes serta wajib pajak orang pribadi yang memiliki usaha.

Berdasarkan kriteria tersebut maka didapatkan jumlah sampel yang digunakan sebanyak 50 responden sehingga total kuisioner yang diolah sebanyak 50 (lima puluh). Instrumen penelitian diukur menggunakan model skala likert 5 poin. Metode analisis data yang digunakan dalam penelitian ini adalah analisis regresi linier berganda menggunakan program SPSS versi 22 (Ghozali, 2016). Adapun persamaan regresi linier berganda digambarkan dalam bentuk sebagai berikut :

$$
\mathrm{Y}=\mathrm{a}+\mathrm{b}_{1} \mathrm{X}_{1}+\mathrm{b}_{2} \mathrm{X}_{2}+\mathrm{b}_{3} \mathrm{X}_{3}+\mathrm{e}
$$

\section{HASIL}

Hasil uji validitas untuk masing-masing pertanyaan dapat dilihat pada tabel 1 berikut ini :

Tabel 1 Hasil Uji Validitas

\begin{tabular}{|c|c|c|c|c|}
\hline Variabel & pertanyaan & Person Corelation & Sig. (2-tailed) & Keterangan \\
\hline \multirow{4}{*}{ Tingkat Pendapatan (X1) } & 1 & 0,866 & 0,000 & VALID \\
\cline { 2 - 5 } & 2 & 0,886 & 0,000 & VALID \\
\cline { 2 - 5 } & 3 & 0,383 & 0,006 & VALID \\
\cline { 2 - 5 } & 5 & 0,389 & 0,005 & VALID \\
\hline \multirow{5}{*}{ Penurunan Tarif (X2) } & 1 & 0,548 & 0,000 & VALID \\
\cline { 2 - 5 } & 2 & 0,689 & 0,000 & VALID \\
\cline { 2 - 5 } & 3 & 0,677 & 0,000 & VALID \\
\cline { 2 - 5 } & 4 & 0,431 & 0,000 & VALID \\
\cline { 2 - 5 } & 5 & 0,775 & 0,000 & VALID \\
\hline \multirow{5}{*}{ Perubahan Cara Pembayaran (X3) } & 6 & 0,708 & 0,000 & VALID \\
\cline { 2 - 5 } & 1 & 0,624 & 0,000 & VALID \\
\cline { 2 - 5 } & 2 & 0,547 & 0,000 & VALID \\
\cline { 2 - 5 } & 3 & 0,519 & 0,000 & VALID \\
\cline { 2 - 5 } & 5 & 0,532 & 0,000 & VALID \\
\cline { 2 - 5 } & 6 & 0,727 & 0,000 & VALID \\
\hline \multirow{5}{*}{ Kepatuhan Wajib Pajak (Y) } & 1 & 0,475 & 0,000 & VALID \\
\cline { 2 - 5 } & 2 & 0,524 & 0,000 & VALID \\
\cline { 2 - 5 } & 3 & 0,722 & 0,000 & VALID \\
\cline { 2 - 5 } & 4 & 0,776 & 0,000 & VALID \\
\cline { 2 - 5 } & 5 & 0,588 & 0,000 & VALID \\
\cline { 2 - 5 } & 6 & 0,721 & 0,000 & VALID \\
\hline
\end{tabular}


Berdasarkan tabel 1 di atas diketahui bahwa hasil uji validitas menggunakan Pearson Correlation menunjukkan bahwa setiap pertanyaan dari seluruh variabel memiliki nilai signifikansi $<0,05$ yang artinya seluruh pertanyaan dalam variabel dinyatakan valid.

Hasil uji reliabilitas untuk masing-masing pertanyaan dapat dilihat pada tabel 2 berikut ini :

Tabel 2. Hasil Uji Reliabilitas

\begin{tabular}{|l|c|c|}
\hline \multicolumn{1}{|c|}{ Variabel } & Cronbach's Alpha & Keterangan \\
\hline Tingkat Pendapatan $\left(\mathrm{X}_{1}\right)$ & 0,775 & Reliabel \\
\hline Penurunan Tarif $\left(\mathrm{X}_{2}\right)$ & 0,776 & Reliabel \\
\hline Perubahan Cara Pembayaran $\left(\mathrm{X}_{3}\right)$ & 0,727 & Reliabel \\
\hline Kepatuhan Wajib Pajak $(\mathrm{Y})$ & 0,769 & Reliabel \\
\hline
\end{tabular}

Berdasarkan tabel 2 diatas menunjukkan bahwa nilai Cronbach's Alpha pada keseluruhan variabel dalam penelitian ini lebih dari 0,60 yang artinya keseluruhan variabel adalah reliabel.

Hasil uji normalitas dapat dilihat pada tabel 3 berikut ini :

Tabel 3. Hasil Uji Normalitas

\begin{tabular}{|l|l|r|}
\hline \multicolumn{2}{|c|}{ One-Sample Kolmogorov-Smirnov Test } \\
\hline N & Standardized Residual \\
\hline Normal Parameters & \multicolumn{1}{|c|}{, } \\
& Mean & .0000000 \\
\cline { 2 - 3 } & Std. Deviation & .96890428 \\
\hline $\begin{array}{l}\text { Most Extreme } \\
\text { Differences }\end{array}$ & Absolute & .084 \\
\cline { 2 - 3 } & Positive & .084 \\
\cline { 2 - 3 } & Negative & -.074 \\
\hline Test Statistic & & .084 \\
\hline Asymp. Sig. (2-tailed) & $.200^{\mathrm{c}, \mathrm{d}}$ \\
\hline
\end{tabular}

Berdasarkan tabel 3 di atas diketahui bahwa hasil uji normalitas dengan One-Sample Kolmogorov-Smirnov Test menunjukan nilai signifikansi (2-tailed) sebesar 0,200 > alpha 0,05 yang berarti data berdistribusi normal.

Hasil uji heterokedastisitas dapat dilihat pada tabel 4 berikut ini :

Tabel 4. Hasil Uji Heterokedastisitas

\begin{tabular}{|c|c|c|c|c|c|c|}
\hline \multicolumn{7}{|c|}{ Coefficients $^{a}$} \\
\hline \multirow{2}{*}{\multicolumn{2}{|c|}{ Model }} & \multicolumn{2}{|c|}{$\begin{array}{l}\text { Unstandardized } \\
\text { Coefficients }\end{array}$} & \multirow{2}{*}{$\begin{array}{c}\begin{array}{c}\text { Standardized } \\
\text { Coefficients }\end{array} \\
\text { Beta } \\
\end{array}$} & \multirow{3}{*}{$\frac{\mathrm{t}}{260}$} & \multirow{3}{*}{$\frac{\text { Sig. }}{.796}$} \\
\hline & & $\mathrm{B}$ & Std. Error & & & \\
\hline & (Constant) & 708 & 2.722 & & & \\
\hline & Tingkat_Pendapatan & -.109 & .108 & -.162 & $\begin{array}{c}- \\
1.008\end{array}$ & .319 \\
\hline & Penurunan_Tarif & .067 & .108 & .100 & .621 & .538 \\
\hline & Perubahan_Cara_Pembayaran & .042 & .083 & .078 & .510 & .613 \\
\hline
\end{tabular}

Berdasarkan tabel 4 di atas menunjukkan bahwa nilai signifikansi variabel tingkat pendapatan sebesar 0,319>0,05, variabel penurunan tarif sebesar $0,538>0,05$ dan variabel perubahan cara 
pembayaran sebesar 0,613 >0,05 sehingga dapat disimpulkan bahwa semua variabel tidak terkena gejala heterokedastisitas.

Hasil uji multikolinearitas dapat dilihat pada tabel 5 berikut ini :

Tabel 5. Hasil Uji Multikolinearitas

Coefficients $^{\mathrm{a}}$

\begin{tabular}{||l|c|c|}
\hline \multicolumn{1}{|c|}{} & \multirow{2}{*}{ Model } & \multicolumn{2}{c|}{ Collinearity Statistics } \\
\cline { 2 - 3 } & Tolerance & VIF \\
\hline (Constant) & & \\
\hline Tingkat_Pendapatan & .821 & 1.217 \\
\hline Penurunan_Tarif & .813 & 1.229 \\
\hline Perubahan_Cara_Pembayaran & .902 & 1.109 \\
\hline
\end{tabular}

Berdasarkan tabel 5 di atas menunjukkan bahwa nilai tolerance dari semua variabel menunjukkan angka $>0,10$ dan nilai VIF dari semua variabel menunjukkan angka kurang dari $<10$ sehingga dapat disimpulkan bahwa dalam penelitian ini model regresi tidak terkena gejala multikolinearitas.

Hasil uji regresi linier berganda dapat dilihat pada tabel 6 berikut ini :

Tabel 6. Hasil Persamaan Regresi

\begin{tabular}{|c|c|c|c|c|c|c|}
\hline \multicolumn{7}{|c|}{ Coefficients $^{a}$} \\
\hline \multirow{2}{*}{\multicolumn{2}{|c|}{ Model }} & \multicolumn{2}{|c|}{$\begin{array}{l}\text { Unstandardized } \\
\text { Coefficients }\end{array}$} & $\begin{array}{l}\text { Standardized } \\
\text { Coefficients }\end{array}$ & \multirow[t]{2}{*}{$\mathrm{t}$} & \multirow[t]{2}{*}{ Sig. } \\
\hline & & B & Std. Error & Beta & & \\
\hline 1 & (Constant) & 1.708 & 4.269 & & .400 & 691 \\
\hline & Tingkat_Pendapatan & .658 & .169 & 462 & 3.886 & .000 \\
\hline & Penurunan_Tarif & .068 & .170 & .048 & .401 & .691 \\
\hline & Perubahan_Cara_Pembayaran & .424 & .130 & .370 & 3.256 & .002 \\
\hline
\end{tabular}

Berdasarkan tabel 6 diatas maka dapat ditulis persamaan regresi sebagai berikut : $\mathrm{Y}=1.708+0,658 \mathrm{X}_{1}+0.068 \mathrm{X}_{2}+0.424 \mathrm{X}_{3}$

Hasil uji parsial (uji t) dapat dilihat pada tabel 7 berikut ini :

Tabel 7. Hasil Uji T

\begin{tabular}{|c|c|c|c|c|c|c|}
\hline \multicolumn{7}{|c|}{ Coefficients $^{\mathbf{a}}$} \\
\hline \multirow{2}{*}{\multicolumn{2}{|c|}{ Model }} & \multicolumn{2}{|c|}{$\begin{array}{l}\text { Unstandardized } \\
\text { Coefficients }\end{array}$} & \multirow{2}{*}{$\begin{array}{c}\text { Standardized } \\
\text { Coefficients } \\
\text { Beta }\end{array}$} & \multirow[b]{2}{*}{$\mathrm{T}$} & \multirow[b]{2}{*}{ Sig. } \\
\hline & & B & Std. Error & & & \\
\hline & (Constant) & 1.708 & 4.269 & & .400 & .691 \\
\hline & Tingkat_Pendapatan & .658 & .169 & .462 & 3.886 & .000 \\
\hline & Penurunan_Tarif & .068 & .170 & .048 & .401 & .691 \\
\hline & Perubahan_Cara_Pembayaran & .424 & .130 & .370 & 3.256 & .002 \\
\hline
\end{tabular}

Berdasarkan tabel 7 di atas menunjukkan bahwa variabel tingkat pendapatan (X1) memiliki nilai signifikansi $0,000<0,005$ sehingga $\mathrm{H}_{1}$ diterima, yang berarti tingkat pendapatan berpengaruh terhadap kepatuhan wajib pajak UMKM masa pandemi covid-19. Sedangkan variabel penurunan tarif (X2) memiliki nilai signifikansi $0,691>0.05$ sehingga $\mathrm{H}_{2}$ ditolak, yang berarti penurunan tarif tidak berpengaruh terhadap kepatuhan wajib pajak UMKM masa pandemi covid-19. Adapun variabel perubahan cara pembayaran (X3) memiliki nilai sigifikansi $0,002<0,05$ sehingga $\mathrm{H}_{3}$ diterima, yang berarti perubahan cara pembayaran berpengaruh terhadap kepatuhan wajib pajak UMKM masa pandemi covid-19. 
Hasil uji simultan (uji F) dapat dilihat pada tabel 8 berikut ini :

Tabel 8. Hasil Uji F

\begin{tabular}{|l|l|c|c|c|c|c|}
\hline \multicolumn{7}{|c|}{ ANOVA $^{\mathbf{a}}$} \\
\hline \multicolumn{2}{|l|}{ Model } & Sum of Squares & df & Mean Square & F & Sig. \\
\hline \multirow{2}{*}{1} & Regression & 232.286 & 3 & 77.429 & 13.363 & $.000^{\mathrm{b}}$ \\
\cline { 2 - 7 } & Residual & 266.534 & 46 & 5.794 & & \\
\cline { 2 - 7 } & Total & 498.820 & 49 & & & \\
\hline
\end{tabular}

Berdasarkan tabel 8 di atas menunjukkan bahwa nilai signifikansi pada uji $\mathrm{F}$ yaitu sebesar 0,000 $<$ alpha 0,05 sehingga variable tingkat pendapatan, penurunan tarif dan perubahan cara pembayaran berpengaruh secara simultan terhadap kepatuhan wajib pajak UMKM masa pandemi covid-19.

Hasil uji koefisien determinasi dapat dilihat pada tabel 9 berikut ini :

Tabel 9 Hasil Uji Koefisien Determinasi

\begin{tabular}{|l|c|r|r|r|}
\hline \multicolumn{4}{|c|}{ Model Summary $^{\mathbf{b}}$} \\
\hline Model & R & R Square & Adjusted R Square & Std. Error of the Estimate \\
\hline 1 & $.682^{\mathrm{a}}$ & .466 & .431 & 2.407 \\
\hline
\end{tabular}

Berdasarkan tabel 9 di atas menunjukkan bahwa kontribusi pengaruh tingkat pendapatan, penurunan tarif, dan perubahan cara pembayaran secara bersama-sama terhadap kepatuhan wajib pajak sebesar 0,431 atau $43,1 \%$, sedangkan sisanya $56,9 \%$ dijelaskan oleh variabel lainnya. Hal tersebut menunjukan bahwa ketiga variable tersebut cukup memberikan pengaruh yang signifikan terhadap kepatuhan wajib pajak UMKM di masa pandemi covid-19.

\section{PEMBAHASAN}

\section{Pengaruh Tingkat Pendapatan Terhadap Kepatuhan Wajib Pajak UMKM}

Berdasarkan hasil uji $\mathrm{t}$ diketahui bahwa variabel tingkat pendapatan berpengaruh signifikan terhadap kepatuhan wajib pajak UMKM masa pandemi covid-19 pada KPP Pratama Tegal. Hasil penelitian ini menunjukkan bahwa tingkat pendapatan seseorang sangat mempengaruhi kepatuhan dalam memenuhi kewajibannya. Berdasarkan hasil observasi sebagian besar wajib pajak UMKM merasa lebih patuh ketika mereka memperoleh pendapatan yang tinggi. Pada masa pandemi covid-19 banyak wajib pajak UMKM yang merasa keberatan ketika membayar pajaknya karena memperoleh pendapatan yang rendah. Mereka cenderung menolak atau tidak mau membayar pajaknya karena kebanyakan dari mereka lebih mementingkan kebutuhan pokoknya dibandingkan untuk membayar pajak. Hal ini menunjukkan bahwa semakin tinggi tingkat pendapatan yang diterima maka semakin meningkat kepatuhan wajib pajak UMKM. Sebaliknya semakin rendah pendapatan yang diterima maka semakin menurunnya tingkat kepatuhan wajib pajak UMKM. Hasil penelitian ini diperkuat dengan hasil penelitian dari Ernawati (2014) menyatakan bahwa variabel tingkat pendapatan berpengaruh secara positif terhadap kepatuhan wajib pajak KPP pratama Bulukumba (Ernawati, 2014). Selain itu hasil penelitian ini sejalan juga dengan penelitian sebelumnya yang dilakukan oleh Megantara (2017) yang hasil penelitiannya menyatakan bahwa variabel penghasilan wajib pajak berpengaruh secara positif dan signifikan terhadap kepatuhan wajib pajak usahawan atas penerapan Peraturan Pemerintah Nomor 46 Tahun 2013(Megantara et al., 2017) . Hasil penelitian yang sama juga oleh Yuliyanah et. al (2018) yang menyatakan bahwa omzet penghasilan berpengaruh secara parsial terhadap kepatuhan wajib pajak UMKM di Kota Tegal (Yuliyanah et al., 2019).

\section{Pengaruh Penurunan Tarif Terhadap Kepatuhan Wajib Pajak UMKM}

Berdasarkan hasil uji t diketahui bahwa variabel penurunan tarif tidak berpengaruh terhadap kepatuhan wajib pajak UMKM masa pandemi covid-19 pada KPP Pratama Tegal. Tarif pajak dalam penelitian ini tidak berpengaruh signifikan karena pada masa pandemi covid-19 wajib pajak cenderung mengabaikan besarnya tarif pajak. Hal tersebut dapat ditunjukan dengan masih terdapat wajib pajak yang tidak mengetahui adanya penurunan tarif pajak UMKM dari $1 \%$ menjadi $0,5 \%$ dan wajib pajak 
masih tetap membayar pajak dengan tarif berapapun. Pada dasarnya jika wajib pajak adalah seseorang yang patuh dan mengerti akan kewajibannya sebagai wajib pajak, maka mereka akan membayar pajak dengan tingkatan tarif pajak berapapun sesuai dengan penghasilannya. Jika wajib pajak adalah seseorang yang tidak patuh terhadap kewajibannya sebagai wajib pajak, maka tarif pajak yang rendah pun tidak mempengaruhi tingkat kepatuhannya. Dapat diartikan bahwa naik atau turunnya tarif Pajak masih belum bisa mempengaruhi peningkatan ataupun penurunan kepatuhan wajib pajak UMKM. Hasil penelitian ini selaras dengan penelitian yang dilakukan oleh Yusro dan Kiswanto (2014) yang menyatakan bahwa tarif pajak tidak berpengaruh terhadap kepatuhan wajib pajak UMKM Di Kabupaten Jepara (Yusro, 2014). Selain itu juga hasil penelitian Mir'atusholihah (2014) menyatakan bahwa tarif pajak berpengaruh negatif terhadap kepatuhan wajib pajak UMKM di KPP Pratama Malang Utara (Mir'atusholihah et al., 2014).

\section{Pengaruh Perubahan Cara Pembayaran Terhadap Kepatuhan Wajib Pajak UMKM}

Berdasarkan hasil uji t diketahui bahwa variabel perubahan cara pembayaran berpengaruh terhadap kepatuhan wajib pajak UMKM masa pandemi covid-19 pada KPP Pratama Tegal. Hasil penelitian ini menunjukkan bahwa perubahan cara pembayaran dari manual ke online mempermudah wajib pajak UMKM dalam membayar pajak yang akan berdampak pada kepatuhan wajib pajak. Pada masa pandemi covid-19 keharusan untuk membayar pajak secara online menjadi pilihan yang tepat bagi wajib pajak. Dimana direktorat jendral pajak membuat kebijakan untuk membatasi pelayanan tatap muka kepada wajib pajak. Perubahan cara pembayaran yang bisa dilakukan dimana saja dan kapan saja bahkan lebih mudah dan lebih cepat dengan menggunakan website www.pajak.go.id sehingga dapat meningkatkan kepatuhan wajib pajak UMKM dalam memenuhi kewajibannya. Hal ini berarti perubahan cara pembayaran pajak dapat meningkatkan kepatuhan wajib pajak UMKM sehingga semakin baik Cara Pembayaran pajak yang digunakan oleh Wajib Pajak UMKM maka Kepatuhan Wajib Pajak UMKM akan semakin baik. Hasil penelitian ini didukung oleh penelitian dari Wahyuningsih (2016) yang menyatakan bahwa mekanisme pembayaran pajak berpengaruh positif signifikan terhadap kepatuhan wajib pajak UMKM bidang mebel di Surakarta (Wahyuningsih, 2016).

\section{KESIMPULAN}

Berdasarkan hasil penelitian dan pembahasan yang telah dilakukan maka dapat disimpulkan bahwa hasil pengujian hipotesis pertama menunjukkan bahwa variabel tingkat pendapatan memiliki nilai signifikansi sebesar $0,000<0,05$ sehingga $\mathrm{H}_{1}$ diterima. Hal ini berarti tingkat pendapatan wajib pajak berpengaruh terhadap kepatuhan wajib pajak UMKM masa pandemi covid-19. Selanjutnya, hasil pengujian hipotesis kedua menunjukkan bahwa variabel penurunan tarif memiliki nilai signifikansi sebesar 0,691 >0,05 sehingga $\mathrm{H}_{2}$ ditolak. Hal ini berarti penurunan tarif wajib pajak tidak berpengaruh terhadap kepatuhan wajib pajak UMKM masa pandemi covid-19. Sedangkan, hasil pengujian hipotesis ketiga menunjukkan bahwa variabel perubahan cara pembayaran memiliki nilai signifikansi sebesar $0,002<0,05$ sehingga $\mathrm{H}_{3}$ diterima. Hal ini berarti perubahan cara pembayaran wajib pajak berpengaruh terhadap kepatuhan wajib pajak UMKM masa pandemi covid-19.

\section{SARAN}

Bagi peneliti selanjutnya disarankan untuk memperluas objek penelitian, menambah jumlah sampel yang diteliti, dan meneliti variabel lain yang lebih berpengaruh terhadap kepatuhan wajib pajak UMKM pada masa pandemi covid-19.

\section{REFERENSI}

E. Handayani. (2018). Analisis Perilaku Wajib Pajak Terhadap Penerapan Sistem E-Billing Direktorat Jenderal Pajak [Universitas Islam Negeri Syarif Hidayatullah]. In Universitas Islam NegeriSyarif Hidayatullah (Vol. 1, Issue 1).

Ernawati. (2014). Pengaruh Tingkat Pemahaman Wajib Pajak dan Kualitas Pelayanan Fiskus terhadap Tingkat Kepatuhan Wajib Pajak. Skripsi, 1-24.

Ghozali, I. (2016). Aplikasi Analisis Multivariate Dengan Program IBM SPSS 22 (Edisi 5). Badan Penerbit Universitas Diponegoro.

Haswidar, H. (2016). Pengaruh Tingkat Pendapatan, Pengetahuan, Dan Kesadaran Wajib Pajak 
Terhadap Kepatuhan Membayar Pajak Bumi Dan Bangunan Di Kecamatan Pammana Kabupaten Wajo. In Skripsi.

Marasabessy, I. L. (2020). Pengaruh Penurunan Tarif Pajak UMKM Terhadap Kepatuhan Wajib Pajak UMKM (Studi Kasus Pada KPP Pratama Pondok Aren). Skripsi.

Megantara, K., Purnamawati, I. G. A., \& Sinarwati, N. K. (2017). Pengaruh Penghasilan Wajib Pajak, Sosialisasi Perpajakan, dan Kemauan Membayar Pajak Terhadap Kepatuhan Wajib Pajak Usahawan atas Penerapan Peraturan Pemerintah Nomor 46 tahun 2013. E-Journal S1 Ak, 7(1), 110.

Mir'atusholihah, Kumadji, S., \& Ismono, B. (2014). Pengaruh pengetahuan perpajakan, kualitas pelayanan fiskus, dan tarif pajak terhadap kepatuhan wajib pajak (studi pada wajib pajak UMKM di Kantor Pelayanan Pajak Pratama Malang Utara). Jurnal Mahasiswa Perpajakan, 3(1), 1-10.

Nadhor, K. (2019). Pengaruh Penurunan Tarif Pajak Umkm Dan Pelayanan Online Terhadap Persepsi Wajib Pajak Mengenai Kepatuhan Wajib Pajak Umkm Di Kantor Pelayanan Pajak Pratama Semarang Barat (Vol. 1, Issue 1) [UIN Walisongo Semarang].

Ramdan, A. N. (2017). Pengaruh Perubahan Tarif,Metode Penghitungan dan Modernisasi Sistem Pajak Terhadap Kepatuhan Wajib Pajak UMKM Dengan Keadilan Pajak Sebagai Variabel Moderasi Pada UMKM Di Kota Makasar. In Universitas Islam Negeri Alauddin, Makassar (Vol. 53, Issue 9). Universitas Islam Negeri Alauddin, Makassar.

Sangadji, E. M. A. S. (2010). Metodologi Penelitian - Pendekatan. CV. Andi Offset.

Sugiyono, S. (2016). Statistika Untuk Penelitian. Alfabeta.

Sukrisno \& Estralita. (2012). Akuntansi Perpajakan (2nd ed.). Salemba Empat.

Syah, A. langgeng N., \& Krisdiyawati. (2017). Analisis Faktor - Faktor Yang Mempengaruhi Kepatuhan Wajib Pajak Dalam Membayar Pajak Kendaraan Bermotor (Studi Empiris Pada Kantor UPPD/Samsat Brebes). Jurnal AKSI (Akuntansi Dan Sistem Informasi), 2, 65-77.

Wahyuningsih, T. (2016). Pengaruh Pemahaman Wajib Pajak, Tarif Pajak, Mekanisme Pembayaran Pajak Dan Kesadaran Wajib Pajak Terhadap Kepatuhan Wajib Pajak UMKM Bidang Mebel Di Surakarta. In Institut Agama Islam Negeri Surakarta (Vol. 147).

Yuliyanah, P. R., R, D. N., \& Fanani, B. (2019). Pengaruh Omzet Penghasilan, Tarif Pajak, Serta Self Assessment System Terhadap Kepatuhan Wajib Pajak Usaha Mikro, Kecil Dan Menengah (Umkm) Di Kota Tegal. Multiplier: Jurnal Magister Manajemen, 3(1). https://doi.org/10.24905/mlt.v3i1.1286

Yusro, H. W. \& K. (2014). Pengaruh Tarif Pajak, Mekanisme Pembayaran Pajak Dan Kesadaran Membayar Pajak Terhadap Kepatuhan Wajib Pajak Umkm Di Kabupaten Jepara. Accounting Analysis Journal, 3(4), 429-436. https://doi.org/10.15294/aaj.v3i4.4201 